\title{
Ethnobotany Study of Traditional Feed and Medicine for Cows and Goats Cattles in Bawean Island
}

\author{
Faizah Nur Faridah $^{1}$, Iis Nur Asyiah ${ }^{1 *}$, Ika Lia Novenda ${ }^{1}$ \\ ${ }^{1}$ Program Studi Pendidikan Biologi, Fakultas Keguruan dan Ilmu Pendidikan, Universitas Jember, Jl. Kalimantan No. \\ 37, Jember 68121, Indonesia \\ *Corresponding Author: iisnaza@gmail.com
}

\section{ABSTRACT}

Bawean Island is a small island located in the Java Sea, about 80 miles or 120 kilometers north of the city of Gresik, East Java. Bawean Island consists of 2 sub-districts, namely the Sangkapura subdistrict and the Tambak sub-district. Bawean Island has many rice fields, hills, and forests that can meet the needs of cattles and goats. The use of plants as feed and traditional medicine for cattles and goats by breeder on Bawean Island is included in the ethnobotany study. This research aims to know the knowledge of people in utilizing plants as feed and traditional medicine, especially for cattles and goats. This type of research is descriptive-exploratory. Sampling uses Purposive Sampling and Snowball Sampling techniques with open-ended and semi-structured interview types. Based on the results of this study, inventoried 21 species of plants used as feed for cattles, 19 species of plants used as feed for goats, as well as inventoried 33 species of plants used as a traditional medicine for cattles and goats.

Keywords: traditional medicine animal, animal feed, Bawean Island, cattles, goats.

\section{ABSTRAK}

Pulau Bawean merupakan pulau kecil yang terletak di Laut Jawa, berada sekitar 80 mil atau 120 kilometer di sebelah utara Kota Gresik, Jawa Timur. Pulau Bawean terdiri dari 2 Kecamatan, yaitu Kecamatan Sangkapura dan Kecamatan Tambak. Pulau Bawean memiliki banyak persawahan, bukit, dan hutan yang mampu untuk mencukupi kebutuhan hewan ternak sapi dan kambing. Pemanfaatan tumbuhan sebagai pakan dan obat tradisional untuk hewan ternak sapi dan kambing oleh peternak di Pulau Bawean termasuk ke dalam kajian etnobotani. Penelitian ini bertujuan untuk mengetahui pengetahuan masyarakat dalam memanfaatkan tumbuhan sebagai pakan dan obat radisional, khususnya pada hewan ternak sapi dan kambing. Jenis penelitian ini adalah deskriptif-eksploratif. Pengambilan sampel menggunakan teknik Purposive Sampling dan Snowball Sampling dengan tipe wawancara open-ended dan semi terstruktur. Berdasarkan hasil penelitian ini, terinventarisasi 21 spesies tumbuhan yang digunakan sebagai pakan untuk hewan ternak sapi, 19 spesies tumbuhan yang digunakan sebagai pakan untuk hewan ternak kambing, serta terinventarisasi 33 spesies tumbuhan yang digunakan sebagai obat tradisional untuk hewan ternak sapi dan kambing.

Kata Kunci: obat tradisional ternak, pakan ternak, Pulau Bawean, sapi, kambing. 


\section{PENDAHULUAN}

Pulau Bawean merupakan salah satu pulau yang terdapat di Indonesia. Pulau Bawean terletak di Laut Jawa yang berada sekitar 80 mil atau 120 kilometer di sebelah utara Kota Gresik - Jawa Timur [1]. Pulau Bawean hanya terdiri dari 2 Kecamatan, yaitu Kecamatan Sangkapura dan Kecamatan Tambak [2] [3]. Pada tahun 2018, jumlah penduduk di kecamatan Sangkapura sebanyak 69.620 orang, sedangkan di Kecamatan Tambak terdapat sebanyak 39.146 orang [4]. Mayoritas penduduk Pulau Bawean adalah Suku Bawean. Suku Bawean merupakan hasil akulturasi atau pembauran dari beberapa suku yang ada di Indonesia, seperti Madura, Jawa, Sumatera, Sulawesi, dan Kalimantan termasuk budaya dan bahasanya. Hal inilah yang menjadikan Suku Bawean merupakan suku yang unik. Kemudian uniknya lagi adalah beberapa suku yang ada di Pulau Bawean dahulunya mempunyai budaya tersendiri, dan sekarang mereka akhirnya menanggalkan identitas suku mereka dan telah membaur dalam budaya dan bahasa Bawean [5].

Mata pencaharian masyarakat Suku Bawean sebagian besar adalah sebagai nelayan, selain itu mereka juga bermata pencaharian sebagai peternak dan petani. Masyarakat Suku Bawean mempunyai banyak pengetahuan lokal yang masih belum diketahui oleh banyak orang, sehingga dapat digali lebih mendalam untuk dapat mengetahui berbagai pengetahuan lokal yang dimiliki oleh masyarakat Suku Bawean tersebut. Pemanfaatan tumbuhan sebagai pakan dan obat tradisional untuk hewan ternak sapi dan kambing oleh peternak di Pulau Bawean termasuk ke dalam kajian etnobotani. Etnobotani adalah suatu interaksi atau hubungan antara masyarakat dengan lingkungan sekitarnya, khususnya pada tumbuhan [6]. Tumbuhan ini dimanfaatkan oleh manusia untuk kebutuhan sehari-hari, yang dipengaruhi oleh adat-istiadat atau budaya tertentu yang ada di lingkungan sekitarnya. Pengetahuan lokal masyarakat Suku Bawean tentang etnobotani pakan dan obat tradisional untuk hewan ternak sapi dan kambing didapatkan secara turun temurun.

Masyarakat Suku Bawean banyak yang beternak hewan ruminansia, seperti sapi dan kambing. Pada Kecamatan Sangkapura terdapat 3.720 ekor sapi dan 825 ekor kambing [7]. Sedangkan di Kecamatan Tambak terdapat 3.274 ekor sapi dan 3.481 ekor kambing [8]. Sejak dahulu peternak di Pulau Bawean memanfaatkan sumberdaya alam hayati yang ada disekitarnya sebagai pakan dan obat tradisional untuk hewan ternak sapi dan kambing. Hal ini dikarenakan masyarakat yang bertempat tinggal di Pulau Bawean mempunyai akses transportasi dan informasi yang terbatas, sehingga kurang dijangkau oleh pelayanan kesehatan hewan dan keberadaannya juga kurang begitu dirasakan manfaatnya oleh peternak. Kemudian biaya pembelian obat khusus untuk hewan ternak membutuhkan biaya yang relatif mahal. Disamping itu, Pulau Bawean banyak dikelilingi oleh persawahan, bukit, dan hutan yang menyediakan sumberdaya alam yang cukup untuk kebutuhan hewan ternak sapi dan kambing.

Penelitian ini bertujuan untuk mengetahui pengetahuan lokal masyarakat dalam memanfaatkan tumbuhan sebagai pakan dan obat tradisional untuk hewan ternak, khususnya pada hewan ternak sapi dan kambing. Kemudian dengan adanya penelitian ini juga dapat memberikan pengetahuan kepada semua kalangan khususnya pada peternak hewan sapi dan kambing yang ada di Pulau Bawean untuk terus untuk terus dapat meningkatkan kualitas hewan ternaknya yang berfungsi sebagai sumber pangan dan sumber pendapatan bagi peternak. Cara yang dilakukan oleh peternak di Pulau Bawean untuk meningkatkan kualitas hewan ternaknya adalah dengan memberikan pakan sesuai kebutuhan hewan ternak, menerapkan pengobatan tradisional yang tepat, serta mendorong masyarakat untuk melakukan suatu upaya konservasi agar tumbuhan yang dimanfaatkan sebagai pakan dan obat tradisional untuk hewan ternak sapi dan kambing tersebut selalu tersedia disaat kapanpun dibutuhkan. 


\section{METODE PENELITIAN}

Penelitian ini dilakukan di Pulau Bawean mulai dari bulan Agustus 2019 s.d Januari 2020 di dua kecamatan, yaitu Sangkapura dan Tambak. Jenis penelitian ini adalah deskriptif-eksploratif. Pengambilan sampel dalam penelitian ini didasarkan pada teknik Purposive Sampling untuk mendapatkan sampel informan awal, dan Snowball Sampling untuk mendapatkan sampel informan berikutnya. Pada penelitian ini, informan yang dipilih harus memenuhi beberapa kriteria sebagai berikut: 1) penduduk asli, 2) mempunyai pengetahuan lokal mengenai tumbuhan yang digunakan sebagai pakan dan obat tradisional untuk hewan ternak sapi dan kambing, dan 3) mendapatkan pengetahuan tersebut secara turuntemurun.

Teknik pengumpulan data didasarkan atas kegiatan wawancara yang bersifat Semi-Structured dengan menggunakan tipe pertanyaan Open-Ended. Penelitian dilakukan secara participant observation, yaitu ikut terlibat dalam kegiatan sehari-hari masyarakat. Metode pengolahan data yang digunakan pada penelitian ini adalah metode deskripsi kualitatif. Tumbuhan yang dimanfaatkan sebagai pakan dan obat tradisional untuk hewan ternak sapi dan kambing oleh peternak di Pulau Bawean diidentifikasi dengan menggunakan buku acuan Flora of Java karangan C. A. Backer dan R. C. Bakhuizen van Brink, website, dan dibantu oleh dosen yang ahli dalam bidang taksonomi tumbuhan.

\section{HASIL PENELITIAN}

Penelitian dilakukan dengan 41 orang informan. Mata pencaharian informan tersebut, sebagai peternak sebanyak 36 orang dan petani sebanyak 5 orang. Sebagian besar informan berjenis kelamin laki-laki sebanyak 27 orang dan perempuan sebanyak 14 orang. Rentang usia informan ini mulai dari 36-80 tahun. Kemudian berdasarkan tingkat pendidikan, dari 41 orang informan tersebut paling banyak menempuh pendidikan terakhir tamat SD/Sederajat sebanyak 22 orang. Pengetahuan atau informasi yang diperoleh oleh semua informan ini merupakan informasi yang didapatkan secara turun-temurun dari kakek/nenek dan orangtua.

Pada penelitian ini, terinventarisasi 21 spesies tumbuhan yang digunakan sebagai pakan untuk hewan ternak sapi dan 19 spesies tumbuhan sebagai pakan untuk hewan ternak kambing. Nama lokal, nama Indonesia, dan nama ilmiah dari tumbuhan tersebut dapat dilihat pada Tabel 1 dan Tabel 2 berikut.

Tabel 1. Jenis Tumbuhan yang digunakan sebagai Pakan untuk Hewan Ternak Sapi oleh Peternak Suku Bawean

\begin{tabular}{cccc}
\hline \multirow{2}{*}{ No. } & & Nama Tumbuhan & \\
\cline { 2 - 4 } & Nama Lokal & Nama Indonesia & Nama Ilmiah \\
\hline 1 & Arren & Nira & Arenga pinnata \\
\hline 2 & Bedusan & Bandotan & Ageratum conyzoides \\
\hline 3 & Ilalang & Alang-Alang & Imperata cylindrical \\
\hline 4 & Jhegung & Jagung & Portulaca oleracea \\
\hline 5 & Krajep & Krokot & Phyllanthus niruri \\
\hline 6 & Meneran & Meniran & Cocos nucifera \\
\hline 7 & Nyeor & Kelapa & Oryza sativa \\
\hline 8 & Padih & Padi & Mimosa pudica \\
\hline 9 & Potreh Maloh & Putri Malu & Cynodon dactylon \\
\hline 10 & Rebbhe Lapang & Rumput Grinting & Cleome rutidosperma \\
\hline 11 & Rebbhe & Maman Ungu & Paspalum vaginatum \\
\hline 12 & Rebbhe & Rumput Asinan & Digitaria ischaemum
\end{tabular}




\begin{tabular}{llcc}
\hline 14 & Rebbhe & Rumput Kenop & Cyperus kyllingia \\
\hline 15 & Rebbhe & Rumput Kremah & Alternanthera sessilis \\
\hline 16 & Rebbhe & Rumput Mutiara & Hedyotis corymbosa \\
\hline 17 & Rebbhe & Rumput Teki & Cyperus rotundus \\
\hline 18 & Rebbhe & Sisik Betok & Desmodium triflorum \\
\hline 19 & Rebbhe & Suruhan & Peperomia pellucida \\
\hline 20 & Rebbhe & Urang- aring & Eclipta prostrate \\
\hline 21 & Rumput Gajah & Rumput Gajah & Pennisetum purpureum \\
\hline
\end{tabular}

Tabel 2. Jenis Tumbuhan yang digunakan sebagai Pakan untuk Hewan Ternak Kambing oleh Peternak Suku Bawean

\begin{tabular}{cccc}
\hline \multirow{2}{*}{ No. } & & Nama Tumbuhan & \\
\cline { 2 - 4 } & Nama Lokal & Nama Indonesia & Nama Ilmiah \\
\hline 1 & Angsana & Angsana & Pterocarpus indicus \\
\hline 2 & Banten & Kayu Kuda & Lannea grandis \\
\hline 3 & Jeteh Poteh & Jati Putih & Zea mays \\
\hline 4 & Jhegung & Jagung & Psidium guajava \\
\hline 5 & Jembuh Bigih & Jambu Biji & Manihot utilissima \\
\hline 6 & Manggela & Ketela pohon & Swietenia mahagoni \\
\hline 7 & Ma'oni & Mahoni & Cocos nucifera \\
\hline 8 & Nyeor & Kelapa & Muntingia calabura \\
\hline 9 & Keceri & Kersen & Mangifera indica \\
\hline 10 & Pelem & Mangga & Azadirachta indica \\
\hline 11 & Membeh & Mimba & Artocarpus heterophyllus \\
\hline 12 & Nangkah & Nangka & Laurus nobilis \\
\hline 13 & Pelle & Salam India & Leucaena leucocephala \\
\hline 14 & Lamtoro & Lamtoro & Musa paradisiaca \\
\hline 15 & Geddheng & Pisang & Albizia chinensis \\
\hline 16 & Sengon & Sengon & Artocarpus altilis \\
\hline 17 & Sokon & Sukun & Sesbania grandiflora \\
\hline 18 & Toroi & Turi & Hibiscus tiliaceus \\
\hline 19 & Bheruh & Waru & \\
\hline
\end{tabular}

Pada penelitian ini juga terinventarisasi 33 spesies tumbuhan yang digunakan sebagai obat tradisional untuk hewan ternak sapi dan kambing. Nama lokal, nama Indonesia, nama ilmiah, bagian tumbuhan yang digunakan, dan kegunaan dari tumbuhan tersebut dapat dilihat pada Tabel 3 berikut.

Tabel 3. Jenis Tumbuhan yang digunakan sebagai Obat Tradisional untuk Hewan Ternak Sapi dan Kambing oleh Peternak Suku Bawean

\begin{tabular}{cccccc}
\hline No & Nama Lokal & $\begin{array}{c}\text { Nama } \\
\text { Indonesia }\end{array}$ & Nama Ilmiah & $\begin{array}{c}\text { Bagian } \\
\text { Tumbuhan } \\
\text { yang } \\
\text { digunakan }\end{array}$ & Kegunaan \\
\hline 1 & Accem & Asem & $\begin{array}{c}\text { Tamarindus } \\
\text { indica }\end{array}$ & Buah & $\begin{array}{c}\text { Mengobati penyakit } \\
\text { demam, kembung, dan } \\
\text { keracunan }\end{array}$ \\
\hline 2 & Antemon & Mentimun & Cucumis sativus & Buah & $\begin{array}{c}\text { Mengobati penyakit } \\
\text { demam }\end{array}$ \\
\hline
\end{tabular}




\begin{tabular}{|c|c|c|c|c|c|}
\hline 3 & Bedusan & Bandotan & $\begin{array}{l}\text { Ageratum } \\
\text { conyzoides }\end{array}$ & Daun & $\begin{array}{l}\text { Mengobati } \\
\text { kuku busuk }\end{array}$ \\
\hline 4 & Bhebeng mera & Bawang merah & Allium cepa & Umbi & $\begin{array}{l}\text { Mengobati } \\
\text { kembung }\end{array}$ \\
\hline 5 & Bhebeng poteh & Bawang putih & Allium sativum & Umbi & $\begin{array}{l}\text { Mengobati } \\
\text { kuku busuk }\end{array}$ \\
\hline 6 & Cabbih & Cabai & $\begin{array}{l}\text { Capsicum } \\
\text { апnиит }\end{array}$ & Daun & Mengobati keseleo \\
\hline 7 & Cekkor & Kencur & $\begin{array}{l}\text { Kaempferia } \\
\text { galanga }\end{array}$ & Rimpang & $\begin{array}{l}\text { Mengobati penyakit } \\
\text { diare dan keseleo }\end{array}$ \\
\hline 8 & Jembuh Bhigih & Jambu Biji & Psidium guajava & Daun & $\begin{array}{l}\text { Mengobati } \\
\text { diare }\end{array}$ \\
\hline 9 & Jhegung & Jagung & Zea mays & Daun & $\begin{array}{l}\text { Mengobati } \\
\text { diare }\end{array}$ \\
\hline 10 & Jhei & Jahe & $\begin{array}{l}\text { Zingiber } \\
\text { officinale }\end{array}$ & Rimpang & $\begin{array}{ll}\text { Mengobati penyakit } & \text { ingusan, } \\
\text { kembung, } & \text { ingus } \\
\text { keseleo, dan demam }\end{array}$ \\
\hline 11 & Jherruk Nepes & Jeruk nipis & $\begin{array}{c}\text { Citrus } \\
\text { aurantiifolia }\end{array}$ & Buah & $\begin{array}{l}\text { Mengobati penyakit } \\
\text { kurap dan mata merah }\end{array}$ \\
\hline 12 & Kasembu'an & Sembukan & Paederia foetida & daun & $\begin{array}{l}\text { mengobati penyakit } \\
\text { kembung }\end{array}$ \\
\hline 13 & Katapang & Ketapang & $\begin{array}{l}\text { Terminalia } \\
\text { catappa }\end{array}$ & Daun & $\begin{array}{l}\text { Mengobati } \\
\text { kurap }\end{array}$ \\
\hline 14 & Koddhuk & Mengkudu & $\begin{array}{l}\text { Morinda } \\
\text { citrifolia }\end{array}$ & Buah & $\begin{array}{l}\text { Mengobati } \\
\text { sembelit }\end{array}$ \\
\hline 15 & Konyek & Kunyit & Curcuma longa & Rimpang & $\begin{array}{l}\text { Mengobati penyakit } \\
\text { kembung, ingusan, kuku } \\
\text { busuk, diare, kurap, } \\
\text { demam, penyakit kuku } \\
\text { dan mulut }\end{array}$ \\
\hline 16 & Kostela & Pepaya & Carica papaya & Daun dan Getah & $\begin{array}{l}\text { Mengobati penyakit } \\
\text { kembung }\end{array}$ \\
\hline 17 & Lamtoro & Lamtoro & $\begin{array}{c}\text { Leucaena } \\
\text { leucocephala }\end{array}$ & Biji & $\begin{array}{l}\text { Mengobati } \\
\text { cacingan }\end{array}$ \\
\hline 18 & Laos & Lengkuas & Alpinia galanga & Rimpang & $\begin{array}{l}\text { Mengobati penyakit } \\
\text { ingusan, demam, dan } \\
\text { kurap }\end{array}$ \\
\hline 19 & Lempojeng & Lempuyang & $\begin{array}{l}\text { Zingiber } \\
\text { zerumbet }\end{array}$ & Rimpang & $\begin{array}{l}\text { Mengobati penyakit } \\
\text { diare }\end{array}$ \\
\hline 20 & Lidah Buaya & Lidah Buaya & Aloe vera & Daun & \begin{tabular}{l}
\multicolumn{2}{l}{ Mengobati penyakit } \\
kuku busuk dan \\
sembelit
\end{tabular} \\
\hline 21 & Membeh & Mimba & $\begin{array}{c}\text { Azadirachta } \\
\text { indica }\end{array}$ & Daun & $\begin{array}{l}\text { Mengobati } \\
\text { kurap }\end{array}$ \\
\hline 22 & Nangkah & Nangka & $\begin{array}{c}\text { Artocarpus } \\
\text { heterophyllus }\end{array}$ & Daun & $\begin{array}{l}\text { Mengobati } \\
\text { diare }\end{array}$ \\
\hline 23 & Nyeor & Kelapa & Cocos nucifera & Buah & Mengobati keracunan \\
\hline 24 & Pelle & Salam India & Laurus nobilis & Daun & $\begin{array}{l}\begin{array}{l}\text { Mengobati penyakit } \\
\text { demam }\end{array} \\
\end{array}$ \\
\hline 25 & Penang & Pinang & Areca catechu & Buah & $\begin{array}{l}\text { Mengobati } \\
\text { cacingan }\end{array}$ \\
\hline
\end{tabular}




\begin{tabular}{|c|c|c|c|c|c|}
\hline 26 & Sere & Sirih & Piper betle & Daun & $\begin{array}{l}\text { Mengobati penyakit } \\
\text { kurap, mata merah, dan } \\
\text { kuku busuk }\end{array}$ \\
\hline 27 & Serreh & Serai & $\begin{array}{c}\text { Cymbopogon } \\
\text { citratus }\end{array}$ & Batang & $\begin{array}{lr}\text { Mengobati } & \text { penyakit } \\
\text { kembung, } & \text { keseleo, } \\
\text { penyakit kuku dan } \\
\text { mulut }\end{array}$ \\
\hline 28 & Sundilan & Tempuh wiyang & $\begin{array}{c}\text { Emilia } \\
\text { sonchifolia }\end{array}$ & Daun & $\begin{array}{l}\text { Mengobati penyakit } \\
\text { kuku busuk }\end{array}$ \\
\hline 29 & Tales lorju' & Talas & $\begin{array}{l}\text { Colocasia } \\
\text { esculenta }\end{array}$ & Daun & $\begin{array}{l}\text { Mengobati } \\
\text { demam }\end{array}$ \\
\hline 30 & $\mathrm{Te}$ & Teh & $\begin{array}{c}\text { Camellia } \\
\text { sinensis }\end{array}$ & Daun & $\begin{array}{l}\text { Mengobati penyakit } \\
\text { mata merah }\end{array}$ \\
\hline 31 & Tembheko & Tembakau & $\begin{array}{c}\text { Nicotiana } \\
\text { tabacum }\end{array}$ & Daun & $\begin{array}{l}\text { Mengobati penyakit } \\
\text { kurap dan cacingan }\end{array}$ \\
\hline 32 & Temuereng & Temu hitam & $\begin{array}{l}\text { Curcuma } \\
\text { aeruginosa }\end{array}$ & Rimpang & $\begin{array}{l}\text { Mengobati penyakit } \\
\text { ingusan, diare, cacingan, } \\
\text { penyakit kuku dan } \\
\text { mulut }\end{array}$ \\
\hline 33 & Temulabek & Temulawak & $\begin{array}{c}\text { Curcuma } \\
\text { xanthorrhiza }\end{array}$ & Rimpang & $\begin{array}{l}\text { Mengobati penyakit } \\
\text { ingusan, demam, dan } \\
\text { sembelit }\end{array}$ \\
\hline
\end{tabular}

\section{PEMBAHASAN}

Para Peternak di Pulau Bawean memelihara hewan ternak sapi dan kambingnya secara tradisional dengan sistem pemeliharaan semiintensif, yaitu hewan ternak dipelihara dengan cara dikandangkan dan digembalakan. Peternak di Pulau Bawean dalam mendapatkan sumber pakan sapi dan kambing dengan mengambilnya dari alam atau didapatkan secara liar. Pada saat musim hujan, pakan ternak sangat melimpah sehingga hewan ternak jarang untuk dikeluarkan atau digembalakan di tanah lapang. Sedangkan pada saat musim kemarau, hewan ternak lebih banyak digembalakan di tanah lapang yang terdapat banyak rumput. Hal ini dilakukan karena pada saat musim kemarau, peternak kesulitan dalam mendapatkan pakan untuk hewan ternaknya. Selain itu, juga dapat meringankan peternak dalam menyediakan kebutuhan pakan untuk hewan ternaknya.

Jenis pakan untuk hewan ternak ruminansia, khususnya pada sapi dan kambing adalah berupa hijauan. Hijauan merupakan sumber pakan utama dari hewan ternak ruminansia tersebut. Hijauan ini didapatkan peternak dari rumput liar, rumput budidaya, dan hasil sampingan pertanian. Hewan ternak sapi lebih menyukai jerami padi, jerami jagung, serta jenis tumbuhan yang termasuk ke dalam kelompok rumput-rumputan (graminae) [9]. Sedangkan untuk hewan ternak kambing lebih menyukai daun dari beberapa jenis tumbuhan, rumput yang pendek, dan semak-semak [10]. Hewan ternak kambing lebih banyak menyukai beberapa jenis tumbuhan terutama yang mengandung serat tinggi dibandingkan dengan hewan ternak sapi. Selain itu, hewan ternak kambing dapat menyerap nutrisi lebih baik yang terdapat dalam pakan dibandingkan dengan hewan ruminansia yang lainnya [11].

Hewan ruminansia mempunyai sistem pencernaan yang khas dan sempurna, karena makanan pokoknya adalah berupa rumput atau hijauan. Hewan ruminansia memiliki lambung ganda yang terdiri dari empat bagian, yaitu rumen, retikulum, omasum, dan abomasum. Kapasitas keseluruhan dari empat bagian lambung pada hewan ruminansia dimana pada rumen sebesar $80 \%$, retikulum sebesar $5 \%$, omasum sebesar $8 \%$, dan abomasum sebesar 7\% [12]. Hewan ruminansia 
adalah hewan yang mudah sekali untuk beradaptasi dengan berbagai jenis pakan terutama pada pakan yang berserat tinggi dikarenakan hewan tersebut memiliki perut sejati, yaitu rumen yang mampu untuk memfermentasi semua jenis bahan pakan dengan memanfaatkan mikroba yang ada di dalamnya [13].

Hewan ternak sapi diberi pakan sebanyak 3 kali dalam sehari, yaitu pada pagi, siang, dan sore hari. Sedangkan pada hewan kambing diberi pakan sebanyak 2 kali dalam sehari, yaitu pada pagi dan sore hari. Kemudian hewan ternak tersebut diberikan minum sebanyak 2-3 kali dalam sehari. Minum yang diberikan pada hewan ternak berupa larutan garam $(\mathrm{NaCl})$ secukupnya atau dengan takaran tertentu. Garam $(\mathrm{NaCl})$ merupakan salah satu mineral yang dibutuhkan hewan ternak yang berperan dalam proses metabolisme tubuhnya. Mineral ini tidak terdapat pada pakan ternak sehingga untuk memenuhi kebutuhan mineralnya maka air minum untuk hewan ternak ditambahkan dengan sedikit garam [14].

Pemberian pakan dan minum untuk hewan ternak sapi dan kambing apabila telah terpenuhi dan peternak telah menerapkan perawatan yang tepat akan membuat produktivitas hewan ternak tersebut menjadi meningkat. Hal ini juga dapat meningkatkan sumber pangan dan sumber pendapatan bagi masyarakat. Produk hasil dari hewan ternak sapi dan kambing, yaitu daging, susu, bulu, dan kulit. Namun, produk hasil hewan ternak yang berupa daging dan kulit paling banyak dimanfaatkan oleh masyarakat Suku Bawean. Hewan ternak sapi dan kambing oleh peternak di Pulau Bawean biasanya dijual kepada orang pemilik rumah pemotongan hewan. Hasil dari penjualan hewan ternak tersebut dapat meningkatkan sumber pendapatan bagi peternak.

Hewan ternak sapi dan kambing, apabila kebutuhan pakan dan minumnya tidak tercukupi akan menyebabkan lebih mudah untuk terserang oleh suatu penyakit. Penyakit pada hewan ternak merupakan suatu gangguan kesehatan yang terjadi pada hewan ternak yang disebabkan karena gangguan metabolisme, proses degeneratif, keracunan, parasit, prion, cacat genetik, dan infeksi mikroorganisme patogen. Berdasarkan beberapa penyebab penyakit dari hewan ternak tersebut, akibat dari parasit, prion, dan infeksi mikroorganisme patogen merupakan penyebab penyakit yang paling berbahaya yang dapat menular kepada manusia [15]. Penyakit ini apabila menyerang hewan ternak ruminansia, seperti sapi dan kambing maka harus segera dilakukan penanganan agar tidak menyebabkan kematian pada hewan ternak. Adanya penyakit yang bisa menyerang hewan ternak ini dapat mengakibatkan kerugian pada peternak, karena hewan ternak yang terkena penyakit dapat mati secara mendadak.

Berdasarkan dari hasil penelitian ini, diketahui bahwa terdapat 9 jenis penyakit yang dapat menyerang hewan ternak sapi dan 11 jenis penyakit yang dapat menyerang hewan ternak kambing yang ada di Pulau Bawean. Penyakit yang dapat menyerang hewan ternak sapi, yaitu demam, diare, ingusan, kembung, keseleo, kuku busuk, kurap, mata merah, serta penyakit mulut dan kuku. Sedangkan penyakit yang dapat menyerang hewan ternak kambing, yaitu cacingan, demam, diare, ingusan, kembung, keracunan, keseleo, kuku busuk, kurap, mata merah, dan sembelit. Penyakit yang dapat menyerang hewan ternak sapi dan kambing di Pulau Bawean cukup beranekaragam, mulai dari penyakit yang ringan hingga yang berbahaya. Maka dari itu peternak harus memahami dan mengetahui gejala-gejala penyakit tersebut dan cara pengobatan tradisionalnya agar dapat segera dilakukan penanganan awal, sehingga penyakit tersebut tidak sampai parah, dapat segera tertangani dengan baik, serta tidak sampai menyebabkan kematian pada hewan ternak sapi dan kambing.

Famili tumbuhan yang paling banyak digunakan sebagai bahan dalam pembuatan obat tradisional untuk hewan ternak sapi dan kambing adalah berasal dari famili Zingiberaceae. Tumbuhan yang termasuk ke dalam famili Zingiberaceae tersebut berjumlah 7 spesies, yaitu jahe (Zingiber officinale), kencur (Kaempferia galanga), kunyit (Curcuma longa), lempuyang (Zingiber zerumbet), lengkuas (Alpinia galanga), 
temu hitam (Curcuma aeruginosa), dan temulawak (Curcuma xanthorrhiza). Tumbuhan dari famili ini banyak di budidayakan oleh peternak di Pulau Bawean, mereka membudidayakan tumbuhan tersebut di pekarangan dan di sawahnya.

Tumbuhan dari famili Zingiberaceae ini mempunyai beberapa senyawa kimia yang sangat bermanfaat untuk mengobati penyakit pada hewan ternak sapi dan kambing. Oleh karena itu, banyak peternak yang mengggunakan tumbuhan ini sebagai bahan dalam pembuatan obat tradisional untuk hewan ternaknya. Tumbuhan yang termasuk ke dalam famili Zingiberaceae sudah lama digunakan sebagai antibakteri, antiinflamasi, analgesik, dan lainnya. Kandungan senyawa kimia yang ada pada tumbuhan famili Zingiberaceae inilah yang berguna dan membantu dalam mempercepat penyembuhan berbagai penyakit yang dapat menyerang hewan ternak sapi dan kambing [16].

Bagian-bagian tumbuhan yang digunakan oleh peternak di Pulau Bawean sebagai obat tradisional untuk hewan ternak sapi dan kambing ada 7 bagian, yaitu daun, batang, buah, getah, rimpang, umbi, dan biji. Bagian tumbuhan yang paling banyak digunakan sebagai bahan dalam pembuatan obat tradisional ini adalah daun. Daun adalah salah satu bagian yang seringkali digunakan sebagai bahan dalam pembuatan obat tradisional. Hal ini dikarenakan kebanyakan daun mempunyai tekstur yang lembut sehingga lebih mudah untuk diramu atau diolah daripada organ yang lain, mempunyai banyak khasiat karena banyak menghasilkan senyawa metabolit sekunder, dan mudah didapatkan di saat membutuhkan karena proses regenerasinya cepat. Daun merupakan akumulasi fotosintat dari proses fotosintesis yang dapat menghasilkan senyawa organik yang disebut dengan senyawa metabolit sekunder yang mampu untuk menyembuhkan suatu penyakit. Senyawa metabolit sekunder ini paling banyak dihasilkan oleh organ daun. Senyawa metabolit sekunder tersebut, seperti flavonoid, tanin, terpenoid, alkaloid, saponin, dan polifenol [17].

Peternak di Pulau Bawean dalam memperoleh tumbuhan yang digunakan sebagai bahan dalam pembuatan obat tradisional untuk hewan ternak sapi dan kambing didapatkan secara liar, budidaya dan membeli. Berdasarkan data yang telah didapat, bahwa presentase dari peternak yang mendapatkan tumbuhan sebagai obat tradisional secara liar sebesar $62 \%$, budidaya $25 \%$, dan membeli $13 \%$. Peternak lebih banyak yang mendapatkan tumbuhan tersebut secara liar dengan mengambilnya dari pekarangan, sawah, dan hutan karena tumbuhan tersebut digunakan dalam jumlah sedikit atau skala kecil. Akan tetapi, terdapat juga tumbuhan yang harus dibudidayakan karena sudah semakin sulit untuk didapatkan secara liar. Peternak di Pulau Bawean dalam membudidayakan tumbuhan yang dijadikan sebagai obat tradisional untuk hewan ternak sapi dan kambing dengan menanamnya di pekarangan, kebun, dan sawah.

Peternak di Pulau Bawean dalam meramu bagian tumbuhan yang digunakan sebagai obat tradisional untuk hewan ternak sapi dan kambing, sebagian besar mereka mengambilnya dengan jumlah angka yang ganjil. Angka ganjil tersebut, seperti 1, 3, 5, 7, dan seterusnya. Hal ini dilakukan oleh peternak di Pulau Bawean karena mereka menganggap bahwa angka ganjil tersebut melambangkan Tuhan Yang Maha Esa, dan mereka juga menganggap bahwa secara turun-temurun merupakan takaran yang tepat untuk dapat menyembuhkan penyakit pada hewan ternak sapi dan kambing. Selain itu mereka juga mengatakan bahwa dalam agama Islam, angka ganjil dianggap sunnah dan disenangi oleh Nabi Muhammad SAW. karena mayoritas masyarakat Suku Bawean memeluk agama Islam. Sehingga mereka mempercayai bahwa saat meramu bagian tumbuhan dalam jumlah yang ganjil untuk membuat obat tradisional, akan lebih cepat dalam menyembuhkan penyakit yang menyerang hewan ternak sapi dan kambing, karena mereka menganggap hanya dengan pertolongan dari Tuhan Yang Maha Esa dapat membuat hewan ternak sapi dan kambing yang terserang oleh suatu penyakit tersebut dapat sembuh.

Peternak yang ada di Pulau Bawean dalam mengobati hewan ternak sapi dan kambingnya yang 
sakit, selain menggunakan obat tradisional mereka juga biasanya datang kepada dukun atau orang pintar. Peternak tersebut menganggap bahwa orang pintar ini mampu untuk menyembuhkan penyakit pada hewan ternak sapi dan kambing. Beberapa peternak menganggap bahwa penyakit yang menyerang hewan ternaknya tidak hanya terjadi secara alami, akan tetapi juga dapat disebabkan karena adanya kekuatan magis (sihir) yang dikirim oleh seseorang untuk membuat hewan ternak tersebut menjadi sakit. Hal ini dapat mengakibatkan hewan ternak tersebut menjadi mati dan peternak menjadi rugi.

Orang pintar tersebut akan memberikan air yang telah dibacakan dengan mantra, kemudian diberikan pada peternak untuk nantinya dibalurkan atau diminumkan pada hewan ternak sapi dan kambing yang sedang sakit. Mantra yang diucapkan oleh orang pintar tersebut didapatkan secara turuntemurun, dimana mantra yang sering diucapkan adalah berisi pujian kepada Tuhan Yang Maha Esa. Sehingga diharapkan dengan membacakan pujian tersebut dapat menyembuhkan penyakit pada hewan ternak sapi dan kambing melalui perantara air tersebut. Kemudian ada juga orang pintar yang dapat menyembuhkan keseleo pada hewan ternak sapi dan kambing dengan menggunakan tanaman serai yang dipukulkan dan diikat pada bagian kaki hewan ternak yang keseleo sambil dibacakan dengan suatu mantra.

\section{KESIMPULAN}

Hewan ternak sapi dan kambing menyukai jenis tumbuhan yang berbeda-beda walaupun keduanya termasuk ke dalam hewan ruminansia. Hasil dari penelitian ini, terinventarisasi 21 spesies tumbuhan yang digunakan sebagai pakan untuk hewan ternak sapi, 19 spesies tumbuhan yang digunakan sebagai pakan untuk hewan ternak kambing, serta terinventarisasi 33 spesies tumbuhan yang digunakan sebagai obat tradisional untuk hewan ternak sapi dan kambing.

\section{UCAPAN TERIMA KASIH}

Peneliti mengucapkan terima kasih kepada Universitas Jember yang telah memberikan fasilitas sehingga dapat melaksanakan penelitian ini. Kemudian peneliti juga mengucapkan terima kasih kepada semua informan (masyarakat Suku Bawean) yang telah bersedia untuk memberikan informasi terkait dengan penelitian ini, sehingga peneliti dapat mengumpulkan data penelitian yang dibutuhkan.

\section{DAFTAR PUSTAKA}

[1] Fajaruddin, I., dan Heru S. Scrap Guide Book tentang Perjalanan di Pulau Bawean. J Creativitas. 2014;3(1):43-56.

[2] Pemerintah Kabupaten Gresik. 2019. Profil Desa Kecamatan Sangkapura. https://gresikkab.go.id/profil/desa_di_keca matan_sangkapura [Diakses 01 Agustus 2019]

[3] Pemerintah Kabupaten Gresik. 2019. Profil Desa Kecamatan Tambak. https;//gresikkab.go.id/profil/desa_di_keca matan_tambak [Diakses 01 Agustus 2019].

[4] Badan Pusat Statistik Kabupaten Gresik. 2019. Kabupaten Gresik dalam Angka 2018. Gresik: BPS Kabupaten Gresik.

[5] Rosidin. Nilai-Nilai Kerukunan dalam Kearifan Lokal Masyarakat Bawean Gresik. J. $\quad$ Al-Qalam. 2015;21(1):129140.

[6] Iswandono, E., Ervizal A. M. Z., Agus H., dan Nandi K. Pengetahuan Etnobotani Suku Manggarai dan Implikasinya terhadap Pemanfaatan Tumbuhan Hutan di Pegunungan Ruteng. J Ilmu Pertanian Indonesia. 2015;20(3):171-181

[7] Jannah, R. 2018. Kecamatan Tambak dalam Angka 2018. Gresik: Badan Pusat Statistik Kabupaten Gresik.

[8] Fatlaha, D. 2018. Kecamatan Sangkapura dalam Angka 2018. Gresik: Badan Pusat Statistik Kabupaten Gresik. 
[9] Handayanta, E., Lutojo, dan Kurniasih N. Efisiensi Produksi Sapi Potong pada Peternakan Rakyat pada Musim Kemarau di Daerah Pertanian Lahan Kering Kabupaten Gunungkidul. J. of Sustainable Agriculture. 2017;32(1):49-54.

[10] Marhaeniyanto, E., Sri S., Bambang S., dan Ariani, T. M. Inventarisasi Pemanfaatan Daun Tanaman sebagai Sumber Protein dalam Pakan Kambing Peranakan Etawah (Studi Kasus di Dusun Prodosumbul, Desa Klampok, Kecamatan Singosari, Kabupaten Malang. J. Ternak Tropika. 2019;20(1):59-69.

[11] Susanti, S. dan Marhaeniyanto E. Proporsi Penggunaan Berbagai Jenis Daun Tanaman untuk Pakan Ternak Kambing pada Lokasi dan Ketinggian Berbeda di Wilayah Malang Raya. J. Ilmu-Ilmu Peternakan. 2016;26(3):42-52.

[12] Sudarmono, A. S., dan Y. Bambang Sugeng. 2016. Panduan Beternak Sapi Potong. Jakarta: Penebar Swadaya.

[13] Suryani, N. N., Ketut, M. B., dan I Putu A. A. Fermentasi Rumen dan Sintesis Protein Mikroba Kambing Peranakan Etawa yang diberi Pakan dengan Komposisi Hijauan Beragam dan Level Konsentrat Berbeda. $J$. Majalah Ilmiah Peternakan. 2014;17(2):56-60.
[14] Yanuartono., Alfarisa N., Soedarmanto, Indarjulianto, dan Hary P. Peran Mikromineral pada Reproduksi Ruminansia. $J$ Sain Veteriner. 2016;34(2):155-165.

[15] Winarsih, W. H. Penyakit Ternak yang perlu Diwaspadai Terkait Keamanan Pangan. J Cakrawala. 2018;12(2):218-221.

[16] Wandita, G. A., dan Ida M. Review Artikel: Tanaman Suku Zingiberaceae yang Memiliki Aktivitas sebagai Antioksidan. $J$ Farmaka. 2018;16(2):564-571.

[17] Ningsih, D. R., Zusfahair, dan Dwi K. Identifikasi Senyawa Metabolit Sekunder serta Uji Aktivitas Ekstrak Daun Sirsak sebagai Antibakteri. J Molekul. 2016;11(1):101-111. 